- How does the program fit with the teaching/ learning environment of the institution? Is the program teaching what students need to know?

- Is the program a coherent, incremental one with instruction available for all levels of students, freshman through graduate?

- Is there internal evidence of quality and caring? Are instructional materials appropriate and produced attractively?

- Is there recognition of different learning styles?

- Are students taught the type of research strategies necessary for them to become independent learners?

\section{Conclusion}

This brief paper, summarizing the presentation and discussion at the Middle States Commission's workshop, was written to alert those who will be evaluated as well as those doing the evaluations to a changed perspective in the viewpoint of at least one of the major organizations charged with regional accreditation.

The Commission on Higher Education is now alerting institutions to the increased emphasis on educational effectiveness in the accreditation process. Administration, organization, facilities - too often the major focus of attention in the past-will now be examined in terms of their effect on teaching and learning.

We are being told that wonderful library collections are no longer sufficient: students must learn how to use them. We are being told that bibliographic instruction programs are an essential ingredient in the educational process.

Some of us have waited a long time to hear this!

\section{Bibliographic note}

The Commission on Higher Education is one of three divisions of the Middle States Association of Colleges and Schools. The Commission on Higher Education frequently refers to itself as the Middle States Commission on Higher Education, the Middle States Association, or CHE/MSA. It is the official accrediting organization for the states of Delaware, Maryland, New Jersey, New York, Pennsylvania, and for the District of Columbia, Puerto Rico, the Republic of Panama, and the Virgin Islands. Address: 3624 Market Street, Philadelphia, PA 19104.

Commission on Higher Education. Middle States Association of Colleges and Schools. Characteristics of Excellence in Education: Standards for Accreditation. Rev. ed. Philadelphia, 1989. (This is the Commission's primary statement of standards.)

Commission on Higher Education. Middle States Association of Colleges and Schools. Handbook for Evaluation Team Members. Philadelphia, 1989 .

Simmons, Howard L., “An Accreditor's Perspective: Bibliographic Instruction as a Tool for Learning." Speech presented to the Library Association of the City of New York (LACUNY) at Borough of Manhattan Community College. New York City, May 19, 1989.

Simmons, Howard L., "Bibliographic Instruction as a Tool for Learning: An Accrediting Perspective." CHE Letter, Summer 1989, pp. 11-12.

Simmons, Howard L., "Transitions: Retrospect and Prospect; Annual Report of the Executive Director, 1988-89," CHE Letter, Summer 1989.

\title{
Bibliographic instruction or information literacy
}

\author{
By Hannelore Rader \\ Director, University Library \\ Cleveland State University
}

Since the ALA Presidential Committee on Information Literacy issued its final report in January 1989, many librarians, including members of the ACRL Bibliographic Instruction Section (BIS), have been discussing, sometimes heatedly, how information literacy relates to bibliographic instruction. Before the 1989 ALA Annual Confer- ence in Dallas, BIS sponsored a second Bibliographic Instruction Think Tank (the first BI Think Tank was held before the 1981 ALA Annual Conference in San Francisco), to explore the future direction of bibliographic instruction. Details of the second BI Think Tank are provided in "Educational Roles for Academic Libraries," C $\mho R L N e w s$, 


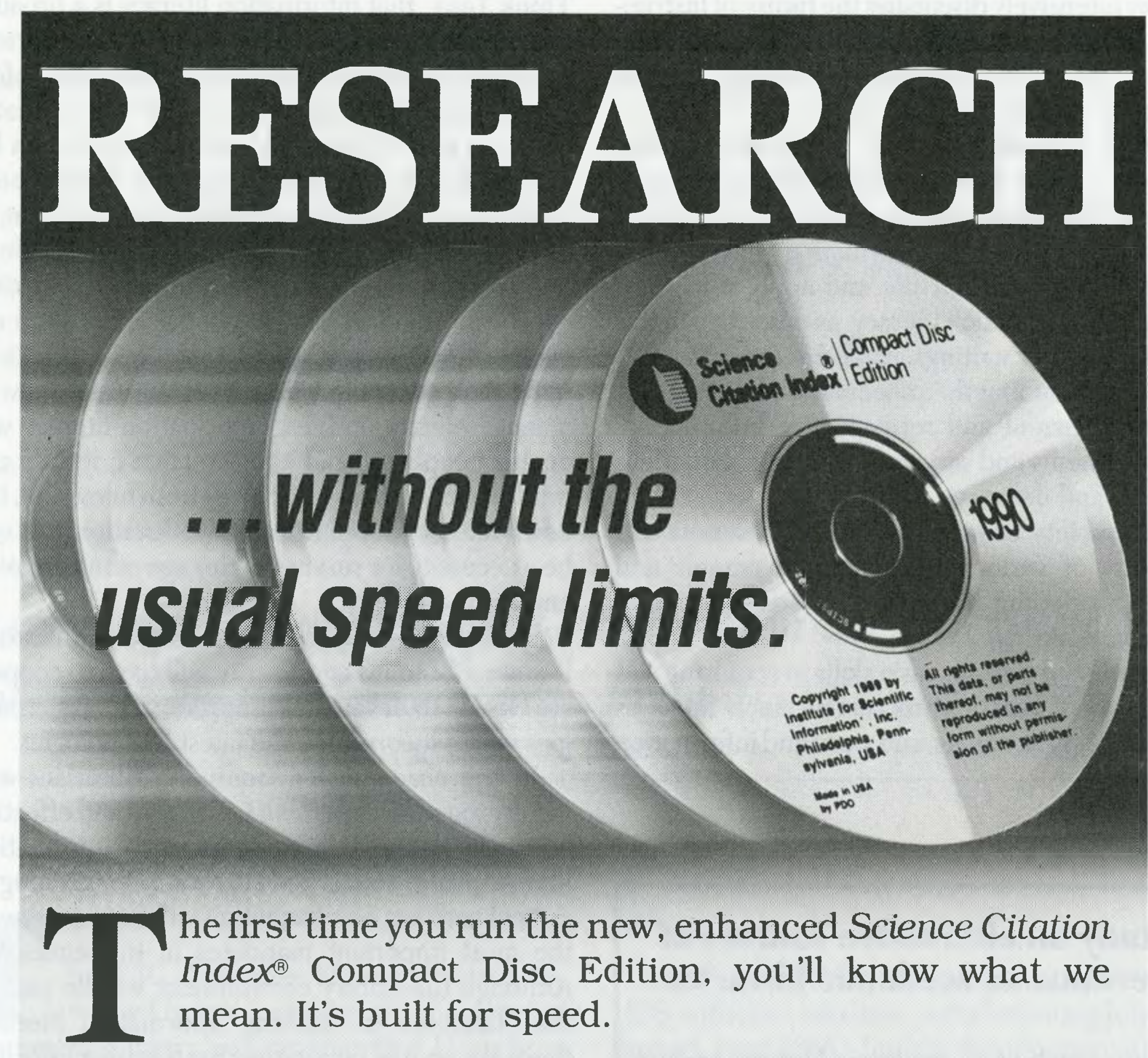

Speed that translates into instant access to the bibliographic data from 3300 sci-tech journals. The journals you depend on to keep your research going full speed ahead.

But the CD Edition does more than go faster-it goes farther. An exclusive hypertext feature called related records leads you to other records having references in common with the ones you've already retrieved ... expanding your search with a few simple keystrokes.

And even though Laserdisk Professional magazine named the SCI ${ }^{\oplus}$ CD Edition "Product of the Year " in 1988, we went back and made it better. Now on a single disc, it's easier than ever to use.

Call us toll-free at: 800- 523-1850, ext. 1405. or write us at the address below to reserve your free trial copy. Also available on CD, the Social Sciences Citation Index ${ }^{\circledR}$ CDE.

Science Citation Index Edition
Institute for Scientific Information ${ }^{\circledR}$ 3501 Market Street Philadelphia, PA 19104 U.S.A. 
December 1989, pp. 984-88. It is noteworthy that nine specially selected academic librarians spent one day intensively discussing the future of instructional programs in academic libraries under the auspices of ALA's Information Library Report during the second BI Think Tank.

The ALA report states that "Information literate people are those who have learned how to learn" because they know how knowledge is organized and can find whatever information they need at whatever point in their life and apply it to solve problems. Information literacy, as described in this report and other writings, can be defined as:

- understanding the processes and systems for acquiring current and retrospective information, such as systems and services for information identification and delivery;

- the ability to evaluate the effectiveness and reliability of various information channels and sources, including libraries, for various kinds of information needs;

- mastering certain basic skills in acquiring and storing one's own information in such areas as databases, spreadsheets, and word and information processing.

\section{Study on alternative sources of revenue in academic libraries}

How much of an academic library's budget comes from sources other than its parent institution? Is the proportion different for public and private institutions? Does it vary by type of institution? If a library does receive some operating budget funds from sources outside the parent institution, how are they obtained?

ALA's Office for Research and ACRL have received a grant from the $\mathrm{H}$. W. Wilson Foundation to try to discover the answers to these questions. A questionnaire has been developed and will be sent out to a scientifically selected sample of academic libraries in the spring of 1989. The sample has been stratified using the categories in the 1987 Carnegie classification.

If you receive one of these questionnaires it is critical that you fill it out. This study can be successful only if we have enough data to determine variations in outside funding experienced by academic libraries. ALA will not release or publish information about any individual library. Your response will help you and other academic librarians learn the extent and nature of these resources.-Anne Beaubien, Chair, ACRL Alternative Sources of Revenue for Academic Libraries Task Force.
It appears from this report, discussions with the library community, and members of the Second BI Think Tank, that information literacy is a broader concept than bibliographic instruction. Information literacy extends the process of learning information skills to all ages and at all times, so that it becomes part of lifelong learning. Information literacy is meant to prepare people for lifelong selfeducation in a global, electronic environment; it extends beyond the library by preparing people to handle information effectively in any given situation. Information literate people are able to organize information searches, evaluate information, build their own online databases, and know how to manage electronic files. Information literacy will enable people to handle information critically and productively, whether it comes from television, the newspaper, or a sophisticated workstation, and will be a necessity for survival in this age of information and technology.

In order to help people become information literate, librarians and faculty will have to cooperate closely to develop appropriate teaching strategies which incorporate the latest technologies.

In the academic environment, librarians and faculty together must plan innovative and effective curricula to teach all students to be information literate professionals and citizens. The teaching of critical analyses of information will become one of the most important mandates in this endeavor. Although the library environment will be part of the classroom in teaching information literacy, there are no real boundaries for teaching information skills. The information can be anywhere, in any format or shape.

Bibliographic instruction or information literacy is not the issue, nor is BI vs. Information Literacy. The issue is that an information literate population is needed to survive in the 21 st century in a technological world. Bibliographic Instruction is part of an evolution toward information literacy, just as library orientation and library instruction was a step toward the evolution of BI.

The question is not that should it be one or the other, but rather, how we can use our Bibliographic Instruction expertise to build strong information literacy programs for the nation by building coalitions with other educational groups and agencies. Our survival depends on it.

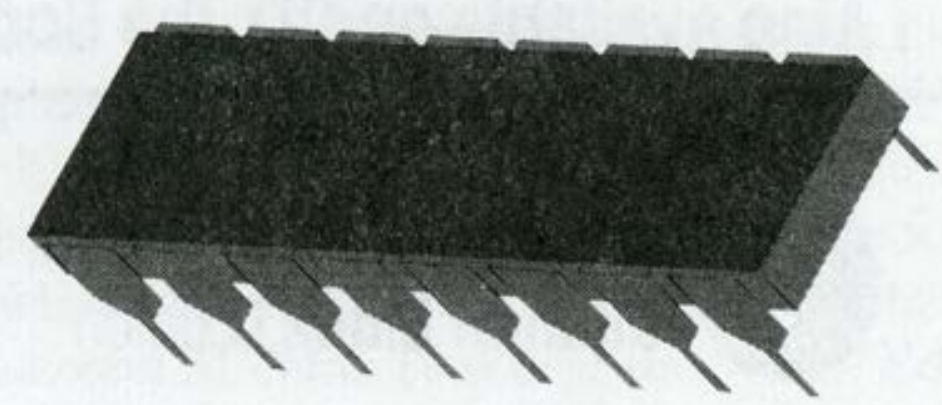

